\title{
INTERACTION BETWEEN RESISTANCE INDUCER AND MICRONUTRIENTS ON THE CONTROL OF ROOT-LESION NEMATODE AND THE DEVELOPMENT OF SOYBEAN PLANTS ${ }^{1}$
}

\author{
NATHALIA SILVEIRA CONDUTA ${ }^{2}$, MONIQUE THIARA RODRIGUES E SILVA ${ }^{3}$, LUANNA KAROLINE \\ RINALDI $^{3 *}$, CLÁUDIA REGINA DIAS-ARIEIRA ${ }^{2}$
}

\begin{abstract}
Root lesion nematodes limit the productivity of several crops of economic importance, requiring alternatives for their management. Resistance inducers activate enzymes involved in defense mechanisms and micronutrients can influence this process by acting as enzymatic cofactors. Thus, the objective of this study was to evaluate the effect of foliar application of a commercial organomineral fertilizer and its association or not with zinc ( $\mathrm{Zn}$ ) and manganese (Mn) micronutrients on the Pratylenchus brachyurus suppression and soybean plant development under greenhouse conditions. Shoots of soybean were treated 10 days after germination and inoculated with 5000 nematodes/plant five days after the treatments, using untreated plants as controls. Treatments consisted of a commercial product based on phosphorylated mannanoligosaccharide derived from the cell wall of Saccharomyces cerevisiae (here coded as MOS), Zn, Mn, $\mathrm{MOS}+\mathrm{Zn}$, MOS $+\mathrm{Mn}$ or $\mathrm{MOS}+\mathrm{Zn}+\mathrm{Mn}$. At sixty days after establishment of treatments, the plants were collected and evaluated for vegetative analysis, nematological analysis and nutrient contents. The work was repeated at different times: experiment 1 from November 2016 to January 2017 and experiment 2 from October to November 2017. All treatments were efficient in controlling P. brachyurus in at least one of the evaluated nematological parameters, compared to the control. However, only the plant spraying with MOS $+\mathrm{Zn}$ results in significative reduction of the total number of nematodes and the number of $P$. brachyurus nematodes per gram of soybean root in both experiments. In addition, spraying of plants with Mn increased shoot dry weight and all treatments resulted in higher concentrations of copper, $\mathrm{Zn}$ and $\mathrm{Mn}$ in soybeans leaves compared to control.
\end{abstract}

keywords: Mannanoligosaccharide. Nutrient. Zinc. Manganese. Pratylenchus brachyurus.

\section{INTERAÇÃO ENTRE INDUTOR DE RESISTÊNCIA E MICRONUTRIENTES NO CONTROLE DO NEMATOIDE DAS LESÕES E NO DESENVOLVIMENTO DE PLANTAS DE SOJA}

\begin{abstract}
RESUMO - Nematoides das lesões radiculares limitam a produtividade de diversas culturas de importância econômica, sendo necessárias alternativas para seu manejo. Os indutores de resistência ativam enzimas envolvidas nos mecanismos de defesa e os micronutrientes podem influenciar esse processo, por atuarem como cofatores enzimáticos. Desta forma, objetivou-se avaliar o efeito da aplicação foliar de um fertilizante organomineral comercial e sua associação com os micronutrientes: zinco (Zn) e manganês (Mn) no controle de Pratylenchus brachyurus e no desenvolvimento da soja. As plantas tiveram sua parte aérea tratada, após 10 dias da germinação e foram inoculadas cinco dias após o tratamento, usando-se plantas não tratadas como testemunha. Os tratamentos consistiram de um produto comercial a base de mannanoligossacarídeos derivados da parede celular de Saccharomyces cerevisiae (aqui codificado como MOS), Zn, Mn, MOS $+\mathrm{Zn}$, MOS $+\mathrm{Mn}$ ou $\mathrm{MOS}+\mathrm{Zn}+\mathrm{Mn}$. Após 60 dias da inoculação, as plantas foram coletadas e avaliadas quanto aos parâmetros vegetativos, nematológicos e teores de macro e micronutrientes. Todos os tratamentos foram eficientes em controlar P. brachyurus em pelo menos um dos parâmetros nematológicos, com redução de 28 a $70 \%$ da população do nematoide comparativamente à testemunha, porém somente o tratamento da soja com $\mathrm{MOS}+\mathrm{Zn}$ resultou em redução significativa da população total de $P$. brachyurus e número de nematoide por grama de raiz nos dois experimentos. Além disso, a pulverização das plantas com Mn proporcionou aumento da matéria seca da parte aérea e todos os tratamentos resultaram em maiores concentrações de cobre, $\mathrm{Zn}$ e Mn nas folhas em comparação a testemunha.
\end{abstract}

Palavras-chave: Mannanoligossacarídeo. Nutriente. Zinco. Manganês. Pratylenchus brachyurus.

\footnotetext{
${ }^{*}$ Corresponding author

${ }^{1}$ Received for publication in $04 / 01 / 2019$; accepted in 05/12/2020.

Paper extracted from undergraduate final project of the first author.

${ }^{2}$ Departament of Agronomic Sciences, Universidade Estadual de Maringá, Umuarama, PR, Brazil; nattyconduta@gmail.com - ORCID: 0000-0002-4420-2080, crdiasarieira@hotmail.com - ORCID: 0000-0002-1567-816X.

${ }^{3}$ Post Graduate in Agronomy, Universidade Estadual de Maringá, Maringá, PR, Brazil; mo_nike_@hotmail.com - ORCID: 0000-00021262-2769, lu.rinaldi@hotmail.com - ORCID: 0000-0002-8458-6947.
} 


\section{INTRODUCTION}

Soybean (Glycine max (L.) Merril) is a crop of economic importance in the national and international scenario, being one of the main agricultural products commercialized worldwide. However, continuous and extensive cultivation has raised concerns regarding the occurrence of pests and diseases, especially nematodes, which may become a limiting factor for the crop.

In recent years, Pratylenchus brachyurus (Godfrey, 1929) Filipjev and Schuurmans Stekhoven became the predominant parasite among nematodes in soybean due to changes in the production system and incorporation of areas with sandy soil, which increased the vulnerability of the crop (ALVES et al., 2011). Changes in the cropping system, such as the adoption of no-till system, succession with host crops, such as soybean and maize, and the gradual growth of soybean cultivation in areas with sandy soils, have increased the losses caused by this pathogen (EMBRAPA, 2010). This nematode is a migratory endoparasite, whose infection causes rupture and destruction of the cortical tissue, causing necrotic lesions which compromise the absorption of water and nutrients; therefore, plants in the field exhibit unequal size and reduction in productivity (ALVES et al., 2011).

The control of this nematode is complex and requires the adoption of an integrated management system, in which priority should be given to practices with a lower environmental impact. Among the alternative management practices, the use of resistance inducers has been demonstrated promising in the control of root lesion nematodes in resistant and susceptible cultivars of maize (PUERARI et al., 2015). Resistance inducers can act in different ways, involving several stages and pathways, but always leading to the activation of plant defense system (RODRIGUES; BEZERRA NETO; COELHO, 2006). Some products not yet registered for resistance induction have demonstrated potential for nematode control, such as MOS (commercial product based on mannanoligosaccharides and nutrients), which has been proven efficient to control Meloidogyne javanica (Treub, 1885) Chitwood (1949) and $P$. brachyurus in soybean (MIAMOTO et al., 2017).

Another factor that may aid in the defense system against pathogens is plant nutrition, particularly micronutrients, which act as enzymatic cofactors and are constituents of some essential enzymes in the defense mechanisms (COUTO et al., 2016). Thus, the hypothesis that micronutrients can improve the efficiency of resistance inducers and favor the control of pathogens is formulated; however, there are no studies regarding this association in the literature. Thus, the objective of this study was to evaluate the efficiency of the MOS based product, isolated or associated with micronutrients, in the control of $P$. brachyurus in soybean.

\section{MATERIAL AND METHODS}

The experiment was carried out in a greenhouse, under the geographic coordinates $23^{\circ}$ $45^{\prime} 59^{\prime \prime} \mathrm{S}, 53^{\circ} 19^{\prime} 30^{\prime \prime} \mathrm{W}$, and $442 \mathrm{~m}$ altitude, in a completely randomized design, with eight treatments and eight replicates, in two different periods: experiment 1 from November 2016 to January 2017 and experiment 2 from October to November 2017. The minimum and maximum average temperatures during each experiment were 20.5 and $30.9^{\circ} \mathrm{C}$ and 18.6 and $29.6{ }^{\circ} \mathrm{C}$, respectively.

Initially, soybean seedlings cv. 'Pintado' were produced in polystyrene trays containing Bioplant ${ }^{\circledR}$ commercial substrate. Five days before transplantation, seedling shoots were sprayed with the doses recommended by the manufacturers, with a product based on mannanoligosaccharide derived from the cell walls of Saccharomyces cerevisiae Meyen (MOS), Zn, Mn, MOS $+\mathrm{Zn}, \mathrm{MOS}+\mathrm{Mn}$ and MOS $+\mathrm{Zn}+\mathrm{Mn}$. The composition and recommended dosage are shown in Table 1. Untreated and inoculated plants and untreated and non-inoculated plants were used as controls.

Table 1. Composition and dosage of the products used in the experimental treatments.

\begin{tabular}{|c|c|c|}
\hline Product & Composition & Dosage \\
\hline $\mathrm{MOS}^{1}$ & $\begin{array}{c}\text { Sulfur } 2.75 \%\left(46.12 \mathrm{~g} \mathrm{~L}^{-1}\right) \text {; Copper } 2.00 \%\left(24.60 \mathrm{~g} \mathrm{~L}^{-1}\right) ; \text { Zinc } 2.00 \% \\
\left(24.60 \mathrm{~g} \mathrm{~L}^{-1}\right) \text {. Density: } 1.23 \mathrm{~g} \mathrm{~cm}^{3} ; \mathrm{pH} 2.84\end{array}$ & $\begin{array}{l}1 \mathrm{~L} \mathrm{ha}^{-1} ; 200 \mathrm{~mL}^{-1} 100 \\
\mathrm{~L}^{-1} \text { of water }\end{array}$ \\
\hline $\begin{array}{l}\text { Metalosate }{ }^{\circledR 2} \\
\text { Zinc }\end{array}$ & $\begin{array}{c}\text { Zinc } 6.8 \%\left(82.26 \mathrm{~g} \mathrm{~L}^{-1}\right) \text {; Contains } 15.0 \% \text { of agent chelating amino acid. } \\
\text { Density: } 1.21 \mathrm{~g} \mathrm{~cm}^{-3}\end{array}$ & $2 \mathrm{~L} \mathrm{ha}^{-1}$ \\
\hline $\begin{array}{l}\text { Metalosate }{ }^{\mathbb{2} 2} \\
\text { Manganese }\end{array}$ & $\begin{array}{c}\text { Manganese } 6.0 \%\left(72.6 \mathrm{~g} \mathrm{~L}^{-1}\right) \text {; Contains } 17.4 \% \text { of agent chelating amino acid. } \\
\text { Density: } 1.21 \mathrm{~g} \mathrm{~cm}^{-3}\end{array}$ & $1.5 \mathrm{~L} \mathrm{ha}^{-1}$ \\
\hline
\end{tabular}

Source: ${ }^{1}$ Agro-Mos ${ }^{\circledR}$, Alltech Crop Science; ${ }^{2}$ Albion ${ }^{\circledR}$ (Product Manufacturers). 
The seedlings were transplanted 15 days after emergence into pots containing $2 \mathrm{~kg}$ of a mixture of soil:sand (2:1), previously autoclaved $\left(120^{\circ} \mathrm{C}\right.$ for $2 \mathrm{~h}$ ). At the transplantation, the seedlings were inoculated with approximately 2,000 P. brachyurus specimens distributed around the soybean plant in a $4 \mathrm{~mL}$ solution volume applied to four holes $(3 \mathrm{~cm}$ deep) in the soil. The inoculum was obtained from a nematode pure population, maintained in soybean plants, whose the specimens were extracted from the root system according to the methodology proposed by Coolen and D'Herde (1972).

The plants were kept in a greenhouse for 60 days and irrigated daily. After this period, they were collected, and each soybean shoot was separated from the respective root system. For the shoots, the height was determined with a millimeter ruler, in which the distance in centimeters from the neck to the insertion point of the last leaf of the plant was considered. For the evaluation of fresh and dry matter of plants, all plants tested were separated into shoot and root system and both parts were weighed separately with the aid of a semi-analytical balance. In order to evaluate the dry weight of each plant, its shoots were kept in drying oven with forced air circulation, at $65{ }^{\circ} \mathrm{C}$, until constant weight was achieved.

The root system was carefully washed and placed on absorbent paper to remove the water excess, then root fresh weight was determined and, subsequently, the nematodes were extracted according to the previously mentioned methodology. After the extraction, the samples were evaluated with the aid of the Peters chamber under an optical microscope, estimating the total number of nematodes and the number of nematodes $\mathrm{g}^{-1}$ of root system.

Four shoot samples from the first experiment, treated with MOS, MOS $+\mathrm{Zn}+\mathrm{Mn}$, non-inoculated control and inoculated control were sent for chemical leaf analysis in a specialized laboratory for determining macro and micronutrient concentrations in soybean leaf (MALAVOLTA; VITTI; OLIVEIRA, 1997).

The data obtained were submitted to analysis of variance at $5 \%$ probability of error and the means were compared by Scott-Knott test at the same level of significance using the statistical program Sisvar (FERREIRA, 2011).

The relationship between nematological, vegetative and nutritional components of plants treated with MOS, MOS $+\mathrm{Zn}+\mathrm{Mn}$, non-inoculated control and inoculated control of the first experiment were studied by Pearson correlation, using the statistical program SPSS 18.0.

\section{RESULTS AND DISCUSSION}

Overall, most of the treatments affected the reproduction of $P$. brachyurus in soybean negatively, reducing the total nematode population by $49 \%$ compared to the control (Table 2). Similar results were observed, in experiment 1 , for P. brachyurus $\mathrm{g}$ 1 of root compared to the control, with average reduction of $58.5 \%$. However, in experiment 2, only the $\mathrm{Zn}$ and $\mathrm{MOS}+\mathrm{Zn}$ treatments showed efficiency in controlling the nematode when compared to the control, with reductions of 74 and $65 \%$, respectively (Table 2). Therefore, there is inequality in the values of the two experiments, this fact may be related to the weather conditions; in experiment 2 the temperature remained lower throughout the experimental conduction, which led to the decrease of nematodes in all treatments compared to the experiment 1 , but either in 2 experiments the results corroborate and showed promising control of $P$. brachyurus, as previously mentioned.

The ideal temperature for population development may vary among Pratylenchus species. For $P$. alleni Ferris, P. brachyurus, $P$. coffeae (Zimmermann) Filipjev and Schuurmans Stekhoven, $P$. neglectus (Rensch) Filipjev and Schuurmans Stekhoven, $P$. scribneri Steiner and $P$. zeae Graham, in soybean the optimum temperature was $30{ }^{\circ} \mathrm{C}$ (ACOSTA; MALEK, 1979). Low temperatures can be lethal to Pratylenchus species and, in general, can lead to marked reductions in their populations at lower temperatures (KOEN; HOGEWIND, 1967).

The results obtained corroborate Miamoto et al. (2017), who studied the application of another product derived from mannanoligosaccharide and found reduction of $M$. javanica and P. brachyurus in soybean. Besides MOS, this product is based on nutrients such as sulfur, copper $(\mathrm{Cu})$ and $\mathrm{Zn}$, and some of these nutrients were reported to have direct or indirect action on root-knot nematodes (RUMIANI et al., 2016). MOS efficiency was observed in reducing bacterial spot severity, with lower disease severity values when the product was applied by foliar spraying than via soil (RODRIGUES; BUENO; TEBALDI, 2016). Despite the lack of information about the direct action of mannanoligosaccharides in the induction of resistance against pathogens, some authors have attributed the positive results obtained by the application of Agro-Mos ${ }^{\circledR}$ to the possibility of this saccharide acting as a signaling molecule (COSTA et al., 2010; FONTOURA et al., 2015). At least in one of the studied treatments, there was significant difference in the reduction of $P$. brachyurus in comparing to control, showing that the application of MOS associated or not with micronutrients $\mathrm{Zn}$ and Mn has the potential to induce resistance, since when applied via shoot, affected the nematode reproduction. Other studies have demonstrated the effect of the MOS on the induction of resistance against several pathogens, with a $70 \%$ reduction in anthracnose (Colletotrichum gloeosporioides (Penz) incidence in papaya fruits (DANTAS et al., 2004),

Rev. Caatinga, Mossoró, v. 33, n. 3, p. 591 - 598, jul. - set., 2020 
besides the control of downy mildew and powdery mildew on grapevine (GOMES; PEREZ; BARBOSA, 2009). Costa et al. (2010) evaluating the application of the same product in cocoa seedlings observed decrease in the incidence of Moniliophthora perniciosa (Stahel) Aime and Philips-Mora, and increased activity of chitinase and $\beta$-1,3-glucanase enzymes, which have direct action on the pathogen, degrading the cell wall and preventing its establishment in the plant. For nematodes, pathogenesis-related proteins such as chitinases, $\beta$-1,3-glucanases, accumulate at a specific site after resistance induction and act directly or indirectly against the phytopathogen (OLIVEIRA; DANTAS; GURGEL, 2004).

Table 2. Total number of specimens of Pratylenchus brachyurus per root system and Nematode $\mathrm{g}^{-1}$ of soybean roots, 60 days after inoculation with 2000 specimens/plant, in two experiments carried out under greenhouse at different times.

\begin{tabular}{lcccc}
\hline \multicolumn{1}{c}{ Treatments } & \multicolumn{2}{c}{ Total number of nematodes/root } & \multicolumn{2}{c}{ Nematode $\mathrm{g}^{-1}$ of root } \\
\hline & Expstem & Exp. 2 & Exp. 1 & Exp. 2 \\
\hline Control & $6663 \mathrm{a}$ & $3305 \mathrm{a}$ & $528 \mathrm{a}$ & $247 \mathrm{a}$ \\
Zinc $(\mathrm{Zn})$ & $7276 \mathrm{a}$ & $1335 \mathrm{~b}$ & $262 \mathrm{~b}$ & $64 \mathrm{~b}$ \\
Manganese (Mn) & $4165 \mathrm{~b}$ & $3217 \mathrm{a}$ & $119 \mathrm{~b}$ & $265 \mathrm{a}$ \\
MOS & $4200 \mathrm{~b}$ & $1182 \mathrm{~b}$ & $155 \mathrm{~b}$ & $267 \mathrm{a}$ \\
MOS+Mn & $4152 \mathrm{~b}$ & $1732 \mathrm{~b}$ & $320 \mathrm{~b}$ & $155 \mathrm{a}$ \\
MOS+Zn & $4792 \mathrm{~b}$ & $987 \mathrm{~b}$ & $135 \mathrm{~b}$ & $86 \mathrm{~b}$ \\
MOS+Mn+Zn & $4452 \mathrm{~b}$ & $1369 \mathrm{~b}$ & $217 \mathrm{~b}$ & $238 \mathrm{a}$ \\
\hline CV (\%) & 43.15 & 31.82 & 72.65 & 70.60 \\
\hline
\end{tabular}

Means followed by the same letter in the columns do not differ by Scott-Knott test at $5 \%$ probability. $\mathrm{CV}=$ coefficient of variation.

Zinc was also efficient in nematode control, reducing the number of $P$. brachyurus per gram of root when applied alone in both experiments, and reduced total nematode population and nematode $\mathrm{g}^{-1}$ of root when used in MOS $+\mathrm{Zn}$ and $\mathrm{MOS}+\mathrm{Zn}+\mathrm{Mn}$ treatments (Table 2). All treatments with $\mathrm{Zn}$ in experiment 2 showed superior results compared to the control reducing the number of $P$. brachyurus for at least one of the parameters evaluated (Table 2). The efficiency of $\mathrm{Zn}$ in the control of $M$. incognita (Kofoid and White, 1919) Chitwood (1949) in tomato has been previously reported, with the reduction of the number of galls and number of nematode eggs at the doses of $60 \mathrm{~L} \mathrm{~g}^{-1}$ of $\mathrm{Zn}$ and reduction in the reproduction at higher doses (COUTO et al., 2016). One of the hypotheses is that plants treated with $\mathrm{Zn}$ may acquire greater resistance to attack by pathogens due to the capability of this element to maintain structure and control membrane permeability. In addition, $\mathrm{Zn}$ acts in the protection of membranes and proteins against oxidation, as it removes $\mathrm{O}_{2}$ toxic radicals. In tissues with $\mathrm{Zn}$ deficiency, higher plasma membrane permeability, carbohydrates and amino acids release may occur, attracting pathogens and insects to roots and shoots (KIRKBY; RÖMHELD, 2007). Thus, there is a greater release of compounds caused by $\mathrm{Zn}$ deficiency, which may lead to a greater attraction of the nematodes to the roots, increasing the infection (STREETER et al., 2001).

Manganese treatments resulted in significantly higher values of SFW, SDW and RFW compared to control. One hypothesis for this is the fact that $\mathrm{Mn}$ plays an important role in photosynthesis, such as electron transport and detoxification of oxygen free radicals. In addition, the breakdown of the water molecule in photosystem II is a unique function of $\mathrm{Mn}$ and its deficiency directly affects photosynthesis, reducing the level of soluble carbohydrates in the plant (KIRKBY; RÖMHELD, 2007).

The Mn application also was significantly efficient in the nematode control when used isolated and in combination with MOS in experiment 1 , and reduced the nematode total population in the treatments $\mathrm{MOS}+\mathrm{Mn}$ and $\mathrm{MOS}+\mathrm{Zn}+\mathrm{Mn}$ in experiment 2 (Table 2). The application of Mn was efficient in reducing the severity of bacterial blight (Xanthomonas axonopodis pv. phaseoli (Smith) Vaut) in common bean by $47 \%$ (VIECELLI; MOERSCHBÄCHER, 2013). However, the appropriate doses of application should be observed, since, in a study evaluating different doses of $\mathrm{Mn}$, it was observed an increase in the severity of wheat spot blotch (Bipolaris sorokiniana (Sacc. in Sorok) Shoemaker)), when the levels of this nutrient were close to deficiency or excess (ZANÃO JÚNIOR; COELHO; FONTES, 2009).

According to Hammerschmidt (1999), the suppressive action of $\mathrm{Mn}$ on the nematode can occur because $\mathrm{Mn}$ acts in the cell as an activator of several enzymes that produce secondary metabolites connected to the shikimic acid pathway, such as phenylalanine ammonia lyase (PAL) and peroxidase, which are pathogenesis-related proteins. The same author mentions that peroxidase is related to the polymerization of alcohols for lignin formation, which also acts as a cofactor of coumarins and 
flavonoids, which makes plants more resistant to nematode attack. This may explain the positive results of this study when using $\mathrm{Mn}$ alone or in combination with AgroMos ${ }^{\circledR}$ for nematode control.

In the present work, in general, plants submitted to the different treatments showed an average increase of $27 \%$ in plant height, when compared to the control. There was also an increase in shoot fresh and dry weight for all treatments when compared to non-inoculated control and, in addition, the lowest averages were observed for inoculated plants (Table 3). These results demonstrate the damage potential of the root-lesion nematode on soybean development, which, in the field, may result in productivity losses.

Table 3. Development of soybean after 60 days of inoculation with 2000 specimens of Pratylenchus brachyurus in experiment 1 .

\begin{tabular}{lcccc}
\hline \multicolumn{1}{c}{ Treatments } & Height $(\mathrm{cm})$ & SFW $(\mathrm{g})$ & SDW $(\mathrm{g})$ & RFW $(\mathrm{g})$ \\
\hline Manganese & $57.71 \mathrm{a}$ & $21.15 \mathrm{a}$ & $6.70 \mathrm{a}$ & $34.34 \mathrm{a}$ \\
Zinc & $57.00 \mathrm{a}$ & $15.94 \mathrm{~b}$ & $5.34 \mathrm{~b}$ & $27.68 \mathrm{~b}$ \\
MOS & $58.50 \mathrm{a}$ & $17.24 \mathrm{~b}$ & $5.59 \mathrm{~b}$ & $26.81 \mathrm{~b}$ \\
MOS+Zn & $53.07 \mathrm{a}$ & $14.65 \mathrm{~b}$ & $4.78 \mathrm{~b}$ & $31.40 \mathrm{a}$ \\
MOS+Mn & $49.16 \mathrm{a}$ & $13.23 \mathrm{~b}$ & $4.34 \mathrm{~b}$ & $19.89 \mathrm{~b}$ \\
MOS+Zn+Mn & $56.71 \mathrm{a}$ & $16.57 \mathrm{~b}$ & $5.48 \mathrm{~b}$ & $25.62 \mathrm{~b}$ \\
Non-inoculated control & $55.21 \mathrm{a}$ & $14.62 \mathrm{~b}$ & $4.39 \mathrm{~b}$ & $27.39 \mathrm{~b}$ \\
Inoculated control & $43.43 \mathrm{~b}$ & $8.65 \mathrm{c}$ & $2.68 \mathrm{c}$ & $14.00 \mathrm{c}$ \\
\hline CV $(\%)$ & 19.67 & 39.25 & 46.23 & 42.18 \\
\hline
\end{tabular}

Means followed by the same letter in the columns do not differ by Scott-Knott test at $5 \%$ probability. CV $=$ coefficient of variation.

$\mathrm{SFW}=$ shoot fresh weight, $\mathrm{SDW}=$ shoot dry weight, $\mathrm{RFW}=$ root fresh weight.

The Zinc treatments significantly increased all vegetative parameters evaluated compared to the non-inoculated control (Table 3), corroborating Oliveira et al. (2017), who observed a positive influence of soybean fertilization with $\mathrm{Zn}$ on vegetative and productive parameters.

The results of the foliar chemical analysis showed that the treatments MOS and MOS associated with $\mathrm{Zn}$ and $\mathrm{Mn}$ increased the concentration of $\mathrm{Cu}$ and $\mathrm{Zn}$ in relation to the inoculated control (Table 4). The MOS $+\mathrm{Zn}+\mathrm{Mn}$ treatment showed a significant difference in the concentration of $\mathrm{Cu}$ in relation to the non-inoculated control (Table 4), while the treatment MOS alone results in reduction of potassium accumulation in the leaves compared to both controls. However, the elements $\mathrm{N}$ (nitrogen), $\mathrm{P}$ (phosphorus), $\mathrm{Ca}$ (calcium), $\mathrm{Mg}$ (magnesium), $\mathrm{S}$ (sulfur), $\mathrm{Fe}$ (iron) and $B$ (boron) did not show significant difference between the treatments evaluated (Table 4).

Table 4. Macro and micronutrient concentrations in soybean leaf after 60 days of inoculation with 2000 Pratylenchus brachyurus specimens in experiment 1 .

\begin{tabular}{|c|c|c|c|c|c|c|c|}
\hline \multirow{2}{*}{ Treatments } & \multicolumn{7}{|c|}{ Macronutrients $\left(\mathrm{cmol} \mathrm{dm}^{-3}\right)$} \\
\hline & $\mathrm{N}$ & $\mathrm{P}$ & $\mathrm{K}$ & & $\mathrm{Ca}$ & & $\mathrm{Mg}$ \\
\hline Without nematode & $21.3^{\mathrm{ns}}$ & $2.0^{\mathrm{ns}}$ & $10.0 \mathrm{~b}$ & & $7.0^{\mathrm{ns}}$ & & $3.6^{\mathrm{ns}}$ \\
\hline With nematode & $17.0^{\mathrm{ns}}$ & $1.6^{\mathrm{ns}}$ & $9.6 \mathrm{~b}$ & & $7.6^{\mathrm{ns}}$ & & $4.3^{\mathrm{ns}}$ \\
\hline MOS & $22.0^{\mathrm{ns}}$ & $1.6^{\mathrm{ns}}$ & $7.0 \mathrm{a}$ & & $7.0^{\mathrm{ns}}$ & & $3.3^{\mathrm{ns}}$ \\
\hline $\mathrm{MOS}+\mathrm{Zn}+\mathrm{Mn}$ & $17.3^{\mathrm{ns}}$ & $1.6^{\mathrm{ns}}$ & $8.6 \mathrm{ab}$ & & $9.0^{\mathrm{ns}}$ & & $3.0^{\mathrm{ns}}$ \\
\hline \multirow[t]{3}{*}{$\mathrm{CV}(\%)$} & 10.85 & 15.80 & 6.57 & & 12.34 & & 9.67 \\
\hline & \multicolumn{7}{|c|}{ Micronutrients $\left(\mathrm{mg} \mathrm{dm}^{-3}\right)$} \\
\hline & $\mathrm{S}$ & $\mathrm{Fe}$ & $\mathrm{Mn}$ & $\mathrm{Cu}$ & & $\mathrm{Zn}$ & B \\
\hline Without nematode & $2.6^{\mathrm{ns}}$ & $98.0^{\mathrm{ns}}$ & $692.3 \mathrm{ab}$ & $9.0 \mathrm{ab}$ & & $40.3 \mathrm{a}$ & $28.6 \mathrm{a}$ \\
\hline With nematode & $3.3^{\mathrm{ns}}$ & $104.0^{\mathrm{ns}}$ & $452.6 \mathrm{~b}$ & $7.3 \mathrm{c}$ & & $22.3 \mathrm{~b}$ & $32.0 \mathrm{a}$ \\
\hline MOS & $2.3^{\mathrm{ns}}$ & $93.0^{\mathrm{ns}}$ & $858.3 \mathrm{a}$ & $12.3 \mathrm{bc}$ & & $40.6 \mathrm{a}$ & $27.6 \mathrm{a}$ \\
\hline $\mathrm{MOS}+\mathrm{Zn}+\mathrm{Mn}$ & $3.0^{\mathrm{ns}}$ & $89.6^{\mathrm{ns}}$ & $701.0 \mathrm{ab}$ & $14.3 \mathrm{a}$ & & $37.6 \mathrm{a}$ & $24.0 \mathrm{a}$ \\
\hline CV (\%) & 12.60 & 15.69 & 10.74 & 10.24 & & 5.61 & 6.39 \\
\hline
\end{tabular}

Means followed by the same letter in the columns do not differ by the Tukey test at $5 \%$ probability. ns not significant. $\mathrm{CV}=$ coefficient of variation.

MOS $=$ AgroMos $^{\circledR}$, MOS $+\mathrm{Zn}+\mathrm{Mn}=$ AgroMos $^{\circledR}+\mathrm{Zinc}+$ Manganese.

Rev. Caatinga, Mossoró, v. 33, n. 3, p. 591 - 598, jul. - set., 2020 
The Pearson correlation analysis positively correlated the variable height with $\mathrm{Cu}$ and $\mathrm{Zn}$ (Table 5). There was no significant interaction for the variables $\mathrm{N}, \mathrm{P}, \mathrm{K}, \mathrm{Ca}, \mathrm{Mg}, \mathrm{S}$ and $\mathrm{Mn}$ (Table 5). Regarding root fresh weight, there was a positive correlation with $\mathrm{Mn}, \mathrm{Zn}$ and plant height (Table 5). For shoot fresh and dry weights the correlation was positive for $\mathrm{Mn}, \mathrm{Cu}, \mathrm{Zn}$, height and root fresh weight, and negative for $\mathrm{Mg}$ (Table 5). In addition to these, shoot dry weight also correlated negatively with $\mathrm{K}$ and positively with shoot fresh weight (Table 5). Regarding the nematological variables, there was a positive correlation between nematode total population and calcium. For nematode per gram of root, there was a positive correlation with $\mathrm{S}$ and total nematode population, and negative correlation with root fresh weight (Table 5).

Table 5. Pearson correlation coefficients between nematode and macro and micronutrients, and development of soybean plants after 60 days of inoculation with 2000 Pratylenchus brachyurus specimens in experiment 1.

\begin{tabular}{|c|c|c|c|c|c|c|c|c|c|}
\hline & Treat & $\mathrm{N}$ & $\mathrm{P}$ & K & $\mathrm{Ca}$ & $\mathrm{Mg}$ & S & $\mathrm{Fe}$ & $\mathrm{Mn}$ \\
\hline $\mathrm{Ca}$ & .335 & -.229 & .144 & .157 & 1 & & & & \\
\hline $\mathrm{Mg}$ & -.567 & .150 & .489 & .552 & -.009 & 1 & & & \\
\hline S & .069 & . 153 & 209 & .427 & .498 & .561 & 1 & & \\
\hline $\mathrm{Fe}$ & -.164 & .447 & .324 & .483 & -.292 & .333 & 0.48 & 1 & \\
\hline $\mathrm{Mn}$ & .257 & $.666^{*}$ & -.055 & -.318 & .050 & -.266 & .018 & .094 & 1 \\
\hline $\mathrm{Cu}$ & $.706^{*}$ & .164 & -.070 & -.293 & $.619^{*}$ & -.544 & .140 & -.193 & .558 \\
\hline $\mathrm{Zn}$ & .156 & .532 & .268 & -.255 & .058 & -.404 & -.322 & .033 & $.772^{* *}$ \\
\hline B & -.482 & .398 & .369 & .518 & -.076 & $.868^{* *}$ & $.657^{*}$ & .321 & -.087 \\
\hline Heig & .167 & .396 & .322 & -.168 & .163 & -.419 & -.291 & -.100 & .508 \\
\hline RFW & 196 & .411 & .070 & -.461 & -.141 & -.413 & -.575 & .129 & $.690^{*}$ \\
\hline SFW & .473 & .407 & -.195 & -.562 & .031 & $-.642^{*}$ & -.385 & -.057 & $.779^{* *}$ \\
\hline SDW & .557 & 297 & -.255 & $-.603^{*}$ & .141 & $-.704^{*}$ & -.323 & -.212 & $.747^{* *}$ \\
\hline TN & $.645^{*}$ & -.435 & -.425 & -.115 & $.654^{*}$ & -.179 & .561 & -.361 & -.020 \\
\hline \multirow[t]{2}{*}{$\mathrm{NG}$} & .320 & -.488 & -.351 & .104 & .464 & .179 & $.671^{*}$ & -.264 & -.308 \\
\hline & $\mathrm{Cu}$ & $\mathrm{Zn}$ & B & Heig & RFW & SFW & SDW & $\mathrm{TN}$ & NG \\
\hline $\mathrm{Cu}$ & 1 & & & & & & & & \\
\hline $\mathrm{Zn}$ & $.581^{*}$ & 1 & & & & & & & \\
\hline B & -.347 & -.330 & 1 & & & & & & \\
\hline Heig & $.650^{*}$ & $.833^{* *}$ & -.217 & 1 & & & & & \\
\hline RFW & .388 & $.792^{* *}$ & -.390 & $.670^{*}$ & 1 & & & & \\
\hline SFW & $.703^{*}$ & $.783^{* *}$ & -.464 & $.697^{*}$ & $.860^{* *}$ & 1 & & & \\
\hline SDW & $.787^{* *}$ & $.765^{* *}$ & -.524 & $.694^{*}$ & $.766^{* *}$ & $.978^{* *}$ & 1 & & \\
\hline TN & .537 & -.273 & -.082 & -.162 & -.407 & -.037 & .119 & 1 & \\
\hline NG & .118 & $-.617^{*}$ & .255 & -.446 & $-.708^{* *}$ & -.460 & -.333 & $.871^{* * *}$ & 1 \\
\hline
\end{tabular}

*significant at $5 \%$ probability, $* *$ significant at $1 \%$ probability. Heig= height $(\mathrm{cm}), \mathrm{RFW}=$ root fresh weight $(\mathrm{g}), \mathrm{SFW}=$ shoot fresh weight $(\mathrm{g}), \mathrm{SDW}=$ shoot dry weight $(\mathrm{g}), \mathrm{TN}=$ total nematode population, $\mathrm{NG}=$ nematode per gram of root.

In a study by Oliveira et al. (2017) they observed that $\mathrm{Zn}$ application promoted increase in plant height, shoot dry mass and soybean root mass, with the highest averages observed for the higher doses of $\mathrm{Zn}$. The results also corroborate the present study (Table 5). El Sayed et al. (2015) verified a $5.05 \%$ increase in the height of soybean plants, with $\mathrm{Zn}$ foliar application. Zinc is an important element for the growth of plants acting as activator of several enzymes, in auxin metabolism and associated with nitrogen. Plants with high $\mathrm{Zn}$ content have faster cellular division and elongation, increased protein synthesis, greater root development and thus increased growth (SADEGHZADEH, 2013).

Copper, in turn, is a constituent of several important proteins in the photosynthesis process, respiration, detoxification of superoxide radicals and lignification. Its deficiency results mainly in a decrease in electron transport, reducing the photosynthetic rate, starch and soluble carbohydrates concentrations, causing a reduction in dry weight, which can cause apical death and short internodes in soybean plants (MASCARENHAS et al., 2013). Garcia, Silva and Secco (2009), evaluating times of application and doses of $\mathrm{Cu}$ and $\mathrm{Zn}$ in soybean, observed that the application of $\mathrm{Cu}$ oxides at dose of $1.88 \mathrm{~mL} \mathrm{~kg}^{-1}$ of soybean seeds and $109 \mathrm{~mL}$ via leaf, and also $4.24 \mathrm{~mL}$ of $\mathrm{Zn}$ oxide per kilogram of soybean seeds, and $245 \mathrm{~mL}$ via leaf, promoted an increase in plant height, corroborating this study, whose correlation is positive between $\mathrm{Cu}$ and plant height (Table 5).

The various beneficial effects of $\mathrm{Zn}$ and $\mathrm{Cu}$ on the vegetative development of plants also influenced the parameters of shoot fresh and dry weights in this work, which were positively correlated and the root weight interacting positively with $\mathrm{Zn}$ (Table 5). Micronutrients linked to 
carbohydrate metabolism by photosynthesis, such as $\mathrm{Zn}$, have a greater effect on plant production parameters, such as plant dry mass (MELARATO et al., 2002). Santos et al. (2008), studying doses of $\mathrm{Cu}$ and $\mathrm{Zn}$ in sorghum seeds, observed increases in weight of 100 seeds and germination speed index, emergence speed index and dry mass of seedlings when treated with these nutrients and also found that seedlings from seeds treated especially with $\mathrm{Cu}$ showed increases in vigor. The same variables showed a positive interaction with $\mathrm{Mn}$ and height (Table 5).

The variable total nematode population correlated positively with $\mathrm{Ca}$ (Table 5) and the hypothesis for this is the increase in the infection sites, since the increase in $\mathrm{Ca}$ concentration allows for greater growth and development of new roots (ANAND; MATSON; SHARMA, 1995).

Positive correlation was also observed between nematological parameters and sulfur, which can be explained by the fact that this micronutrient regulates cell growth, resulting in a larger number of cells and thus increasing the amount of healthy tissue (ZHAO et al., 2014). As a consequence, there may be a reduction in food competition between nematode specimens, allowing greater reproduction.

The negative correlation observed between the number of nematodes per gram of root and $\mathrm{Zn}$ (Table 5) may be due to factors already discussed, including membrane structural maintenance and permeability control. At higher concentrations of $\mathrm{Zn}$, there may be less nematode penetration, decreasing the number of nematodes per gram of root. The negative correlation with root weight (Table 5) was already expected, since the increase in the number of nematodes, may be related with the higher number of lesions in the roots, reducing their total weight.

\section{CONCLUSIONS}

All treatments showed positive effects in reducing $P$. brachyurus at least one of the evaluated nematological parameters, however, the treatment with mannanoligosaccharide derived product associated with zinc was efficient in the control of total nematode population and nematode per gram of root in both experiments.

The Mn treatment was more efficient in increasing shoot fresh and dry weights and root fresh weight. In addition, treatments with the mannanoligosaccharide-derived product isolated or in association with zinc and manganese increased the concentrations of $\mathrm{Cu}, \mathrm{Zn}$ and $\mathrm{Mn}$ in the leaves compared to the inoculated control.

\section{REFERENCES}

ACOSTA, N.; MALEK, R. B. Influence of temperature on population development of eight species of Pratylenchus on soybean. Journal of Nematology, 11: 229-232, 1979.

ALVES, T. C. U. et al. Reação de cultivares de soja ao nematoide das lesões radiculares Pratylenchus brachyurus. Revista Biodiversidade, 10: 73-79, 2011.

ANAND, S. C. K.; MATSON, W.; SHARMA, S. B. Effect of soil temperature and $\mathrm{pH}$ on resistance of soybean to Heterodera glycines. Journal of Nematology, 27: 478-482, 1995.

COOLEN, W. A.; D'HERDE, C. J. A. Method for the quantitative extraction of nematodes from plant tissue. 1. ed. Ghent, BEL: State Nematology and Entomology Research Station, 1972. 77 p.

COSTA, J. C. B. et al. Indução de resistência em mudas de cacaueiro contra Moniliophthora perniciosa por produto à base de mannanoligossacarídeo fosforilado. Tropical Plant Pathology, 35: p. 285-294, 2010.

COUTO, E. A. A. et al. Boron and zinc inhibit embryonic development, hatching and reproduction of Meloidogyne incognita. Acta Agriculturae Scandinavica, 66: 346-352, 2016.

DANTAS, S. A. F. et al. Indutores de resistência na proteção do mamão contra podridões pós-colheita. Summa Phytopathologica, 30: 304-319, 2004.

EL SAYED, S. A. A. et al. Micronutrient and compost induced changes of growth, yield, nutrient and phytochemical content of canola grown in saline soil. American-Eurasian Journal of Sustainable Agriculture, 9: 16-22, 2015.

EMPRESA BRASILEIRA DE PESQUISA AGROPECUÁRIA - EMBRAPA. Nematoides em soja: identificação e controle. Londrina: Embrapa Soja, p. 7, 2010. Disponível em: http:// www.cnpso.embrapa.br/download/ CT76_eletronica.pdf. Acesso em: 25 out. 2017.

FERREIRA, D. F. Sisvar: a computer statistical analysis system. Ciência e Agrotecnologia, 35: 1039-1042, 2011.

KOEN, H.; HOGEWIND, W. L. Symptoms and characteristics of Pratylenchus brachyurus infestation on stored potatoes. South Africa Journal of Agricultural Science, 10: 543-550, 1967. 
FONTOURA, D. et al. Disease resistance induction in second-season corn using acibenzolar-S-methyl and phosphorylated mannanoligosaccharide. Semina: Ciências Agrárias, 36: 3657-3664, 2015.

GARCIA, G. G.; SILVA, T. R. B.; SECCO, D. Épocas de aplicação e doses de fertilizantes a base de cobre e zinco no rendimento de grãos de soja. Cultivando o Saber, 2: 18-25, 2009.

GOMES, E. C. S.; PEREZ, J. O.; BARBOSA, J. Resistência induzida como componente do manejo de doenças da videira. Engenharia Ambiental, 6: 114-120, 2009.

HAMMERSCHMIDT, R. Phytoalexins: What have we learned after 60 years? Annual Review of Phytopathology, 37: 285-306, 1999.

KIRKBY, E. A.; RÖMHELD, V. Micronutrientes na fisiologia de plantas: funções, absorção e mobilidade. Piracicaba, SP: IPNI, 2007. 24 p. (Encarte de Informações Agronômicas, 118).

MALAVOLTA, E.; VITTI, G. C.; OLIVEIRA, S. A. Avaliação do estado nutricional das plantas: princípios e aplicações. 2. ed. Piracicaba, SP: POTAFOS, 1997. 319 p.

MASCARENHAS, H. A. A. et al. Deficiência e toxidade visuais de nutrientes em soja. Nucleus, 10: 281-306, 2013.

MELARATO, M. et al. Manganês e potencial fisiológico de sementes de soja. Ciência Rural, 32: 1069-1071, 2002.

MIAMOTO, A. et al. Alternative products for Pratylenchus brachyurus and Meloidogyne javanica management in soybean plants. Journal of Phytopathology, 165: 635-640, 2017.

OLIVEIRA, F. C. et al. Diferentes doses e épocas de aplicação de zinco na cultura da soja. Revista de Agricultura Neotropical, 4: 28-35, 2017.

OLIVEIRA, S. M. A.; DANTAS, S. A. F. D.; GURGEL, L. M. S. Indução de resistência em doenças pós-colheita em frutas e hortaliças. Revisão Anual de Patologia de Plantas, 12: 343-372, 2004.

PUERARI, H. H. et al. Resistance inducers in control of root lesion nematodes in resistant and susceptible cultivars of maize. Phytoparasitica, 43: 383-389, 2015.

RODRIGUES, A. A. C.; BEZERRA NETO E.; COELHO, R. S. B. Indução de resistência a Fusarium oxysporum f. sp. tracheiphilum em caupi: eficiência de indutores abióticos e atividade enzimática elicitada. Fitopatologia Brasileira, 31: 492-499, 2006.

RODRIGUES, V. W. B.; BUENO, T. V.; TEBALDI, N. D. Bioferilizantes no controle da mancha bacteriana (Xanthomonas spp.) do tomateiro. Summa Phytopathologica, 42: 94-96, 2016.

RUMIANI, M. et al. Effect of elemental sulfur on the root-knot nematode, Meloidogyne incognita, activities in cucumber plants. Iranian Journal of Plant Pathology, 52: 85-98, 2016.

SADEGHZADEH, B. A review of zinc nutrition and plant breeding. Journal of Soil Science and Plant Nutrition, 13: 905-927, 2013.

SANTOS, H. C. et al. Qualidade fisiológica de sementes de sorgo em resposta a adubação com zinco. Revista Caatinga, 21: 64-74, 2008.

STREETER, T. C. et al. Zinc fertilisation increases tolerance to Rhizoctonia solani (AG 8) in Medicago truncatula. Plant and Soil, 228: 233-242, 2001.

VIECELLI, C. A.; MOERSCHBÄCHER, T. Controle do crestamento bacteriano na cultura do feijoeiro pelo uso de fertilizantes foliares. Scientia Agraria Paranaensis, 12: 66-72, 2013.

ZANÃO JÚNIOR, L. A.; COELHO, P. H. M.; FONTES, R. L. F. Severidade da mancha-marrom em trigo cultivado com diferentes formas de nitrogênio e doses de manganês. Revista Brasileira de Ciência do Solo, 33: 1199-1206, 2009.

ZHAO, Q. et al. Sulfur nutrient availability regulates root elongation by affecting root IAA levels and the stem cell niche. Journal of Integrative Plant Biology, 56: 1151-1163, 2014. 